\section{THE PRACTICE OF MEDICINE IN THE NEW ENGLAND COLONIES.}

Read before the H.C. Wood Medical Society of the University of Pennsylvania, Oct. 21, 1897.

BY FRANCIS K. PACKARD, M.D.

PHILADELPYIA, PA.

I propose to glance in a cursory manner at a few of the many interesting and curious facts concerning medical practice in the early days of the settlement of New England. It is a subject about which not much has been written and of which our knowledge is very scanty, compared with the thoroughness with which we know every other detail of the lives of the colonists. The truth is that our medical forefathers left but little literary material upon which to work in an investigation of their methods or experiences. But few of them devoted themselves to purely professional work, and their lives were too largely occupied with the battle against the difficulties which lay in the way of developing the new country to afford much chance for scientific or literary labor, had any of them the inclination for it.

In the records of the settlements of the New England colonists we find but few instances in which the expedition was accompanied by a regularly appointed physician or surgeon. In March, 1629, one John Pratt was appointed, by the Court of Assistants in London, as surgeon to the Salem Plantation, upon the condition, "that $£ 40$ should be ailowed him, for his chest $£ 25$, and the residue for his own salary during the first year." This is all we know of poor Pratt. except his untimely end, which is recorded by Governor Winthrop in his history of New England. It appears that in 1645 he sailed for Spain in a vessel built and sailed by Thomas Hawkins of Boston, and that when in sight of the Spanish coast they struck a rock, the vessel sank and Pratt perished. Winthrop says of him: "He was above 60 years of age, an experienced surgeon, who had lived in Now England many years, and was of the first church at Cambridge in Mr. Hooker's time, and had good practice and wanted nothing. But he had long been discontented because his employment was not so protitable to himself as he desired, and it is like he feared lest he should fall into want in his old age."

In April, 1629, the "Governor and Company of the Massachusetts Bay in New England" issued a general letter addressed to John Endicott, the leader of the settlers at Salem, in which they informed him that they had agreed with Lambert Wilson, chirurgeon, that he should act as surgeon to the settlers, and also to the neighboring Indian tribes, for three years, and he further engaged to give a medical training to one or more of the young men of the colony.

These are the only records of the appointment of surgeons to the settlements that I have been able to find.

Our forefathers seem to have placed much confidence in the medical skill of their spiritual and secular authorities. Cotton Mather was regarded as eminent authority on medical subjects, though with a knowledge of his opinions on the subject of witchcraft, one would have been rather disinclined to trust his judgment.

There is extant a manuscript of prescriptions or formulie, which were furnished to John Winthrop, Governor of the Colony of Massachusetts Bay, by a Dr. Ed. Stafford of London, to be used in the treat- ment of various ailments which might afflict the colonists. I have transcribed some of these as illustrative of some of the standard treatments of the day. They were found among the Winthrop Papers and were published in the "Transactions of the Massachusetts Historical Society."

The first is curious, as it brings forth Dr. Stafford's belief in the so-called doctrine of signatures. "For the yellow Jaundise or Jaunders. Boyle a quart of sweet milke, dissolve therein as much bay salt, or salpeter, as shall make it brackish in taste: and putting saffron in a fine linen clout, rubb it into ye Milke, untill ye Milke be very yellow: and give it ye patient to drinke."

It is woll for the people of the Southern States, in which yellow fever is prevalent, that the second prescription I quote is not still in use. It is entitled: "My Black powder against ye plague, smallpox, purple and all sorts of feavers, Poysons; either by Way of prevention, or after Infection. In the Moneth of March take Toades, as many as you will, alive; putt them in an Earthen pott, so yt will be halfe full; Cover it with a broad tyle or Iron plate; then overwhelme the pott so yt ye bottom may be uppermost: putt charcoales round about it and over it, and in the open air, not in an house, sett it on fire and lett it burne out and extinguish of itself: When it is cold, take out the toades; and in an Iron morter pound them very well, and searce them, then in a Crucible calcine them againe: pound and searce them againe. The first time they will be a browne powder, the next time black. Of this you may give a dragme in a Vehiculum (or drinke) Inwardly in any infection taken, and let them sweat upon it in their beddes: but lett them not cover their heads; especially in the Smallpox. For prevention half a dragme will suffice: moderate the dose according to ye strength of the partie, for I have sett downe ye greatest that is needfull. There is no danger in it. Lett them neither eat nor drinke during their sweat, except now and then a spoonfull of Warme posset-drink to wash their mouths. keep Warme and close (for a child of 5 years, 10 graynes is enough in infection, for prevention 4 or 5े graynes.) till they be pefectly well; and eate but little; and that according to rules of physicke."

But there is yet more service for his "Black powder."

"The same powder is used playster wise with Vinegar for a gangrene, or bite of ane Venomous beast, taking it likewise Inwardly: It is used likewise for all Cankers, Fistulas \& old Ulcers \& king's Evill, strewing it upon the sores and keeping them cleane."

The following is his prescription for " $\mathrm{Y}_{\theta}$ Falling sicknesse: Purge first with ye extract of Hellebore (;black hellebore I meane;) and instead of St. John's Wort use pentaphyllon, (or meadow Cinquefoile:) use it as above is said of St. John's Wort, and God willing he shall be perfectly cured in short or longer tyme according as the disease hath taken root."

The list contains a recipe for " $\mathrm{A}$ broken bone, or a joynt dislocated, to knit them: Take ye barke of Elme, or Witch hazzle; cutt away the outward, and cutt ye Inward redd barke small, and boyle it in Water till it be thick that it Will rope: pound it very well, and lay of it hott barke and all upon ye Bone or Joynt, and tye it on: or with ye Mussilage of it, and bole Armeniack make a playster and lay it on."

The bole Armeniack of the prescription is an argillaceous earth, possessing astringent properties. 
Dr. Stafford concludes with the following:

"Nota bene: No man can with a good Conscience take a fee or a reward before ye partio receive benefit apparent: and then he is not to demand anything, but what (tod shall putt into the heart of the partie to give him. And he is not to refuse anything that shall be given him, for it commes from God. A man is not to neglect that partie, to whom he hath once administered, but to visit him at least once a day, and to medle with no more than he can well attend. In so doing he shall discharge a good Conscience before God \& Man. These receipts are all experimented.

ED. STaFFoRd, London May 6, 1643."

The colonists welcomed the arrival of ships having surgeons aboard them and their services were eagerly sought for. Winthrop tells us that in the year 1644 "One of the deacons of Boston Church, Jacob Eliott, (a man of very sincere heart, and an humble frame of spirit,) had a daughter of eight years of age, who being playing with other children about a cart, the hinder end thereof fell upon the child's head and drove a piece of the skull before it into the brain, so as the brains came out, and seven surgeons, (some of the country, very experienced men, and others of the ships which rode in the harbour) being called together for advice etc. did all conclude that it was the brains (being about half a spoonful at one time and more at other times,) and that there was no hope of the child's life, except the piece of skull could be drawn out. But one of the ruling elders of the Church an experienced and very skilful surgeon, liked not to take that course but applied only plasters to it, and withal earnest prayers were made by the church to the Lord for it, and in six weeks it pleased God that the piece of skull consumed, and so came forth, and the child recovered perfectly, nor did it lose the senses at any time."

The Puritans, as is well known, had the most intense belief in the efficacy of prayer, as is evinced in the foregoing anecdote and in the following, also taken from Winthrop: "One Bumstead, a member of the church, had a child of about the same age (as the one above mentioned), that fell from a gallery in the meetinghouse about 18 feet high, and broke the arm and shoulder, (and was also committed to the Lord in the prayers of the Church, with earnest desires that the place where his people assembled to his worship might not be defiled with blood,) and it pleased the Lord also, that this child was soon perfectly recovered."

The first appearance of syphilis in the colonies was of such a curious nature that $I$ have taken the chronicler's text verbatim. It is once more John Winthrop who narrates how this most grievous disease came amongst them. It was in the year 1646:

"There fell out also a loathsome disease at Boston, which raised a scandal upon the town and country, though without just cause. One of the town having gone cooper in a ship into - , at his return his wife was infected with Lues Venerea, which appeared thus; being delivered of a child and nothing then appearing, but the midwife a skilful woman, finding the body sound as any other, after her delivery she had a sore breast, whereupon divers neighbours resorting to her, some of them drew her breast, and others suffered their children to draw her, and others let her child suck them, (no such disease being suspected by any,) by occasion whereof about sixteen persons, men, women, and children, were infected, whereby it came at length to be discovered by such in the town as had skill in physic and surgery, but there was not any in the country who had been practiced in that cure. But (see the good providence of God) at that very season there came by accident a young surgeon ont of the West Indies, who had had experience of the right way of the cure of that disease. He took them in hand and through the Lord's blessing recovered them all in a short time. And it was observed that although many did eat and drink and lodge in bed with those who were infected and had sores, etc., yet none took it of them but by copulation or sucking. It was very doubtful how this disease came at first. The magistrates examined the husband and wife, but could find no dishonesty in either, nor any probable occasion how they should take it by any other, (and the husband was found free of it.) So as it was concluded by $\operatorname{som} \theta$, that the woman was infected by the mixture of so many spirits of men and women as drew her breast, (for thence it began). But this is a question to be decided by physicians."

In times when sickness was rife or an epidemic prevailed, days were set aside for fasting and prayer. The earliest fast day beld for deliverance from sick. ness was kept in Massachusetts, July 3, 1644. The records simply state that "there was much sickness in the land," and do not specify for what particular disease the fast was held.

Judge Sewall in his diary records a case in which prayer seems to have been unduly exciting to the sick man. It seems it was customary, when the patient was declared to be in a dying condition, for his neighbors to gather and make long prayers at his bedside. On Sept. 20, 1690, he writes: "Mr. Moody and I went before the others came to neighbour Hurd who lay dying, where also Mr. Allen came in. Nurse Hurd told her husband who was there and what he had to say; whether he desired them to pray with him; He said with some earnestness, Hold your tongue, which was repeated three times to his wives repeated entreaties; once he said Let me alone or Be quiet (whether that made a fourth or was one of the three do not remem. ber) and My Spirits are gon. At last Mr. Moody took him up pretty roundly and told him he might with some labour have given a pertinent answer. When we were ready to come away Mr. Moody bid him put forth a little Breath to ask prayer, and said it was the last time had to speak to him; At last ask'd him, do you desire prayer, shall I pray with you. $\mathrm{He}$ answered, Ay for God's sake and thank'd Mr. Moody when had done. His former carriage was very startling and amazing to us. About one at night he died. About 11 o'clock I supposed to hear neighbour Mason at prayer with him just as my wife and I were going to bed."

The Judge dabbled a good deal in medicine, and writes in his famous diary very entertainingly of some of his experiences. He strongly advocated prayer at the bedside of the sufferer, as he quaintly expresses it, to "give him a lift Heavenwards." Possibly some might question the therapeutic benefit of a dying man receiving "a lift Heavenwards."

He tells us of a Mr. Brattle he visited, and who informed the Judge that his visits were not welcome; "he plainly told me that frequent visits were prejudicial to him, it provoked him to speak more than his strength would bear, would have me come seldom." The mortality among the early colonists of New 
England was appalling, They died off like sheep. The settlement of Plymouth had been made Dec. 28, 1620 , by 102 settlers, who had landed from the Mayflocer, and during the following January and Feloruary the deaths averaged two and three a day, a very high death rate in such a small community.

Winterbotham says, "the diseases most prevalent in New England were the following; alvine fluxes, Saint Anthony's fire, asthma, atrophy, catarrh, colic; inflammatory, slow, nervous and mixed fevers; pulmonary consumption, quinsy and rheumatism."

It seems probable from contemporary accounts which have descended to us, that many deaths occurred from "galloping consumption." Influenza epidemics swept over the colonies at intervals and were attended by a remarkable fatality. Dysentery was another disease which prevailed in epidemic form throughout New England at various times. Abigail Adams, the wife of President John Adams, has left us in her "Familiar Letters" a most graphic description of the epidemic of dysentery at Braintree, Mass., in the year 1775, in which she lost many relatives and friends.

The scourge which was most dreaded, however, was smallpox. The first medical publication in the colonies was a small pamphlet, entitled "A Brief Rule to Guide the Common People of New England How to Order themselves and theirs in the Smallpox and Measles," by Dr. Thomas Thacher. It was printed in 1677. Dr. Thacher was not only renowned as a physician, but was also the first minister of the famous Old South Church in Boston, and the author of a Hebrew lexicon. His little treatise, he says, was written "not to inform the Learned Physitian that hath much more cause to understand what pertains to this disease than I, but to give some light to those that have not such advantages." He embodies, in a popular form, the current ideas of the day as to the pathology and treatment of the two diseases. $\mathrm{H}_{\theta}$ considers them conjointly, because he thinks smallpox is a disease "whose nature and cure the measles follow."

In April, 1721, Lady Mary Wortley Montague having returned to England from Turkey, introduced there the practice of inoculation for smallpox, which she had learned from the Turks. At about this time the Reverend Doctor Cotton Mather of Boston read in the "Philosophical Transactions" of the London Society an account of inoculation, written by Pylarini and Timoni, two Italians. He asked a number of the leading physicians of Boston to try it, but they all treated the proposition with ridicule, except Dr. Zabdiel Boylston, who was an intimate personal friend of Mather, and one of the leading medical men of the town. June 27, 1721, only two months later than the introduction of the practice into England, Dr. Boyls. ton inoculated his only son, a boy of 13 , and two negro servants. The attempts proved completely successful, but the practice of inoculation brought such a torrent of abuse upon the Doctor as is almost incredible. His fellow practitioners, animated partly by jealousy, partly through ignorance, united almost to a man in reprobation of the custom. He was assaulted in the streets, his house was attacked by a mob, and a bomb was thrown into the parlor in which his wife was siting. But in spite of all opposition the method of inoculation prevailed and Dr. Boylston's triumph was soon complete. Hutchinson in his "History of Massachusetts" says, "in the year 1721, and first part of 1722, Dr. Boylston inoculated 247 persons, and 39 were inoculated by other persons, in Boston and its vicinity. Of this number only six died and several of these were supposed to have taken the infection before inoculation. In the same period 5759 took the disease the natural way, of whom 844 died, and many of those who recovered were left with broken constitutions and disfigured countenances." What were known as "classes" were formed for the purpose of being inoculated at the same time, or as it was called, "taking the smallpox together." Many doctors established private hospitals for the inoculation of the smallpox. There were two in the immediate neighborhood of Boston, one at Point Shirley, con. ducted by a Dr. William Barnett, from New Jersey, the other at Castle William, in Boston Harbor, in charge of Dr. Samuel Gelston of Nantucket.

Alice Morse Earle in her amusing little book, "Customs and Fashions in Old New England," quotes an example of the ordinary method of advertisment adopted by those who managed these establishments. It is from the Connecticut Courant of Nov. 30, 1767: "Dr. Uriah Rogers, Jr., of Norwalk County of Fair. field takes this method to acquaint the Publick \& particularly such as are desirous of taking the Small Pox by way of Inoculation, that having had Considerable Experience in that Branch of Practice and carried on the same the last season with great Success; he has lately erected a convenient Hospital for that purpose just within the Jurisdiction Line of the Province of New York about nine miles distant from N. Y. Harbour, where he intends to carry said Branch of Practice from the first of October next to the first of May next. And that all such as are disposed to favour him with their Custom may depend upon being well provided with all necessary accomdations, Provisions \& the best Attendance at the moderate Expence of Four Pounds Lawful Money to Each Patient. That after the first Sett or Class he purposes to give no Occasion for waiting to go in Particular Setts but to admit Parties singly, just as it suits them. As he has another Good House provided near said Hospital, where his family are to live, and where all that come after the first Sett that go into the Hospital are to remain with his Family until they are sufficiently Prepared \& Inoculated \& Until it is apparent that they have taken the infection."

We are glad to relate that Dr. Boylston's rewards for his services to humanity were commensurate to his deservings. He was invited to London by the eminent Sir Hans Sloane, then physician to the Royal Family, and was honored by an invitation to inoculate the Princess Caroline. He was the first American elected a fellow of the Royal Society, and before his departure from England he published, at the request of that Society, an account of his method of practicing inoculation. He returned to Boston, enjoyed a large practice, and lived to the age of 81 in the full possession of his faculties.

Leukemia.-Von Moraczewski concludes from a study of the metabolism in leukemia that it is an affection caused by diminished nutrition, essentially characterized by an insufficient disassimilation of nitrogen and phosphorus, only half of the phosphorus ingested being eliminated. Any medication that would further the metabolism and elimination would be effective, especially thyroiodin, as he has established in one case. Sem. Méd., March 26. 